\title{
Molecular Identification of Podocarpus spp. from Bukidnon and Batanes, Philippines using rbcL sequences
}

\author{
Loren Grace J. Anunciado, Esperanza Maribel G. Agoo and Glenn G. Oyong
}

\begin{abstract}
Podocarpus (Podocarpaceae) consists of approximately 100 species spreading in the tropical and subtropical regions worldwide and also in temperate regions in the Southern Hemisphere. It is often difficult to accurately identify Podocarpus. DNA barcoding technique is helpful to provide rapid and accurate taxonomic identification using a specific DNA region. In this study, unknown Podocarpus samples are identified using rbcL sequences. Leaf samples were collected from Bukidnon and Batanes, Philippines. DNA extraction, PCR amplification and DNA sequencing were consequently conducted. The rbcL sequence of Podocarpus is about $700 \mathrm{bp}$ in length. Molecular identification using Basic Local Alignment Search Tool (BLAST) for nucleotides reveals that the sample from Bukidnon is Podocarpus macrophyllus while that from Batanes is Podocarpus costalis. This identification may be helpful as an addition to the reference library of Podocarpaceae. This may allow researchers unfamiliar with the family's morphology and anatomy make accurate identification.
\end{abstract}

Keywords - Batanes, Bukidnon, conifers, Podocarpus, Philippines, rbcL sequence

\section{INTRODUCTION}

Podocarpus is a genus of conifers, the most numerous and widely distributed of the podocarp family, Podocarpaceae. Podocarpus are evergreen shrubs or trees usually from 1 to 25 meters tall, known to reach 40 meters at times. The leaves are 0.5 to $15 \mathrm{~cm}$ long, lanceolate to oblong or falcate (sickle-shaped) in some species, with a distinct midrib. They are arranged spirally, though in some species twisted to appear in two horizontal ranks. The cones have two to five fused scales, of which only one, rarely two, are fertile, each fertile scale has one apical seed. At maturity, the scales become berry-like, swollen, brightly coloured red to purple and fleshy, and are eaten by birds which then disperse the seeds in their droppings. The male (pollen) cones are 5 to $20 \mathrm{~mm}$ long, often clustered several together. Many species, though not all, are dioecious. There are approximately 104 to 107 species in the genus [1].

Species of Podocarpaceae are of conservation interest

Manuscript received March 29, 2016.

L.G.J. Anunciado is with the Arts and Sciences Program, Father Saturnino Urios University, 8600 Butuan City, Philippines. She is also a PhD student of De La Salle University - Manila, 2401 Taft Avenue, Manila.

E.M.G. Agoo is with the Biology Department, De La Salle University Manila, 2401 Taft Avenue, Manila, Philippines.

G.G. Oyong is with the Molecular Science Unit, Center for Natural Science and Ecological Research, Office of the Vice Chancellor for Research, De La Salle University - Manila, 2401 Taft Avenue, Manila, Philippines. because of their small population sizes and limited habitat. In the International Union for the Conservation of Nature [2], there are twenty-seven species of Podocarpaceae that are included in the red list. Ten species are included under the vulnerable category, 14 species are endangered, and three species are critically endangered. Two species are included in the appendices of the Convention on International Trade in Endangered Species [3]: Podocarpus parlatorei is listed in Appendix I (trade is not allowed) and Podocarpus neriifolius is listed in Appendix III (trade with, some limitations, is allowed).

Podocarpaceae have a minor role in commerce. Nageia nagi, when labeled as Asian bayberry, can legally be sold in the United States of America as an herbal dietary supplement [4]. The seeds are processed into an edible oil that is also used in manufacturing [5]. The young leaves are also edible, but not typically consumed [6]. The conspicuous fleshy reproductive structures (receptacles or epimatium) of Afrocarpus falcatus, Dacrycarpus dacrydioides, Dacrydium cupressinum, Podocarpus elatus, Podocarpus macrophyllus, Podocarpus totara, and Prumnopitys taxifolia are eaten either raw or cooked [6].

Podocarpaceae are also known to have medicinal properties that benefit humans and animals [7, 8]. The receptacles and leaves contain a variety of bio-active compounds such as antioxidants, nordi-terpenes, podocarpic acid, and tatarol (7, $9,10]$. Some of these compounds have antimicrobial, fungistatic, or bacteriostatic properties (7, 11, 12]. Other compounds have cytotoxic properties that may be useful in destroying cancer $(13,14,15,16,17]$.

Accurate identification of Podocarpaceae is often very difficult. The most easily accessed material is usually sterile. If fertile material is present, it is frequently either inaccessible or detached from the tree making it difficult to convincingly associate the fertile and sterile portions. Although sterile material of Podocarpaceae can usually be identified to genus using phyllotaxis and leaf form [18, 19], accurate species identification often requires careful microscopic examination of internal, and external characteristics. Proper use of the existing identification tools requires training in botanical terminology, skill in microtechnique, and familiarity with Podocarpaceae [20].

Thus, DNA barcoding is a technique which is helpful to provide rapid and accurate taxonomic identification using a specific DNA region [21]. It has become a useful tool for species identification $[22,23]$, and discovering new or cryptic species $[24,25]$. With DNA barcoding, universality of primers 
for polymerase chain reaction (PCR) and sequencing is one of the most important criteria [26, 22, 27, 28]. In the core barcode, the primers for rbcL show a high level of universality in land plants [29, 30].

In this study, two species of Podocarpus from Bukidnon and Batanes, Philippines were identified using rbcL sequences.

\section{MATERIALS AND METHODS}

\section{A. Sample collection}

The leaf samples used in this study were from Bukidnon and Batanes, Philippines. Leaf samples from Bukidnon were cleaned with sterile water and then placed individually in small plastic bags with silica gel. These were transported to DLSU Manila and stored frozen until needed for DNA extraction. Samples from Batanes were fresh potted plant material.

\section{B. DNA extraction}

Leaf samples were frozen with liquid nitrogen and poured into powder form. These were temporarily stored in the refrigerator at $4{ }^{\circ} \mathrm{C}$. DNA from individual samples was extracted using the CTAB method as described by Doyle and Doyle [31]. The genomic DNA was dissolved in TE buffer (10 $\mathrm{mmol} / \mathrm{L}$ tris-HCL, $\mathrm{pH}$ 8.0, $1 \mathrm{mmol} / \mathrm{L}$ EDTA) to a final concentration of $40-50 \mu \mathrm{g} / \mu \mathrm{L}$ to avoid any variation in PCR success due to DNA concentration differences. The extracts were consequently subjected to agarose gel electrophoresis $(0.8 \%)$.

\section{PCR amplification and DNA sequencing}

The Polymerase Chain Reaction (PCR) was used to amplify rbcL in a $40 \mu \mathrm{L}$ volume containing: $1 \mathrm{X}$ PCR buffer, $2.5 \mathrm{mM}$ $\mathrm{MgCl}_{2}, \quad 0.3 \mathrm{mM}$ dNTPs, $0.3 \mu \mathrm{M}$ of rbcLa_Forward (5' -ATGTCACCAACAAACAGAGACTAAAGC - 3'), $0.3 \mu \mathrm{M}$ of rbcLa_Reverse (5' - GTYAAATCAAGTCCACCYCG - 3'), 0.05 units Taq, and $1 \mu \mathrm{L}$ genomic DNA. The reaction mixture was incubated for $5 \mathrm{mins}$ at $94^{\circ} \mathrm{C}$, followed by 34 cycles of denaturation at $94^{\circ} \mathrm{C}$ for 40 seconds, primer annealing at $55^{\circ} \mathrm{C}$ for 90 seconds, and extension at $72^{\circ} \mathrm{C}$ for 90 seconds. PCR products were sent to 1 st Base Inc. for sequencing.

\section{Sequence analysis}

The chromatogram of the DNA sequences of the individual samples were viewed, corrected and analysed using Chromas LITE version 2.0 (Technelysium Pty. Ltd., Gold Coast, Australia). The sequences were then compared with available sequences in the Genbank using the Basic Local Alignment Search Tool (BLAST) to determine sequence homology of the species and to confirm the identity of the sequenced sample.

\section{RESULTS AND DISCUSSION}

Podocarpus and the Podocarpaceae were endemic to the ancient supercontinent of Gondwana, which broke up into Africa, South America, India, Australia-New Guinea, New Zealand, and New Caledonia between 105 and 45 million years ago. Podocarpus is a characteristic tree of the Antarctic flora, which originated in the cool, moist climate of southern
Gondwana, and elements of the flora survive in the humid temperate regions of the former supercontinent. As the continents drifted north and became drier and hotter, Podocarpus and other members of the Antarctic flora generally retreated to humid regions, especially in Australia, where sclerophyll genera like Acacia and Eucalyptus became predominant, and the old Antarctic flora retreated to pockets that presently cover only $2 \%$ of the continent. As Australia drifted north toward Asia, the collision pushed up the Indonesian archipelago and the mountains of New Guinea, which allowed podocarp species to hop across the narrow straits into humid Asia, with P. macrophyllus reaching north to southern China and Japan. The flora of Malesia, which includes the Malay peninsula, Indonesia, the Philippines, and New Guinea, is generally derived from Asia but includes many elements of the old Gondwana flora, including several other genera in the Podocarpaceae (Dacrycarpus, Dacrydium, Falcatifolium, Nageia, Phyllocladus, and the Malesian endemic Sundacarpus), and also Agathis in the Araucariaceae [32].

Two unknown species of Podocarpus from Bukidnon and Batanes, Philippines were identified using DNA barcoding techniques. The sample from Bukidnon was coded R1 while the sample from Batanes was coded R3. R1 and R3 are about 700 bp in length (Fig. 1). The sequences of R1 and R3 are shown in Figs. 2 and 3, respectively. Molecular identification using Basic Local Alignment Search Tool (BLAST) for nucleotides gave the following identities: R1 is Podocarpus macrophyllus; R3 is Podocarpus costalis (Table I).

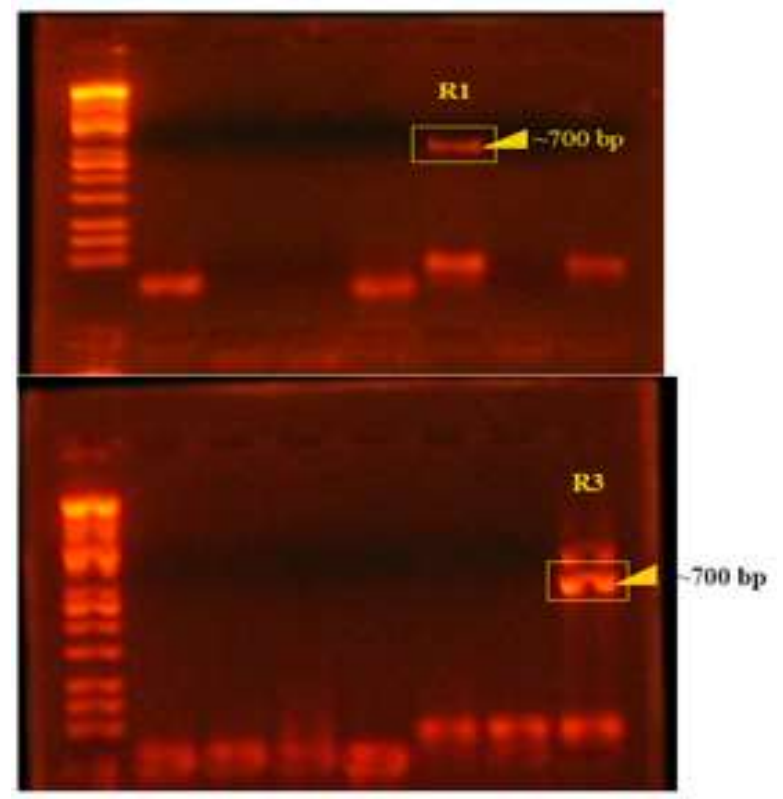

Fig. 1. Gel electrophoresis results of the PCR amplification for the rbcL gene from Podocarpus samples from Bukidnon [R1, (left)] and from Batanes [R3, (right)]. 
$>$ Contig1

ATGTCACCCCAARCAGRGACTAAHGCARGTGCTGGGTTCAAAGCTGGTGTIAAAGATTAC AGATTAACTTATTATACTCCGGAATATCCGACCAAAGATACTGATATCTIGGCGGCATTC CGAGTCACTCCTCAACCCGGAGTGCCCCCCGAGGAAGCAGGAGCGGCAGTAGCTGCCGAA. TCTTCCACTGGTACATGGACTACTGTITGGACCGATGGACTIACCAGCCTCGATCGTTAC AAGGGGCGATGCTATGGCATCGRACCTATTCCTGGRGAAGAAAGTCAATTIATTGCCTAT GTAGCTTATCCCTIAGACCTIITGAAGAAGGIICTGTTACTAACCTGTTCACCTCCATI GTGGGTAATGTTITGGATTCAAAGCCCTACGGGCTATACGTCTGGAAGATCTGCCAATT CCTCCTTCTIATTCCAMACTTTCCARGGTCCCCCACATGGTATCCACGTACAMAGGGAT AARITAARTAAATATGGCCGCCCCTTATTGGGATGIACCATCAARCCAAARTGGGTCTG TCTGCAAAGAATTATGGTAGAGCAGTTTACGAATGTCTTC

Fig. 2. Nucleotide sequence of the Podocarpus sample from Bukidnon.

\section{>Contig1}

CAAACAGAGACTAARGCAGTGCTGEGTCAHACTGGTGTTAAHGATTACAGATTALT TATTAIACTCCGGAATATCCGACCAARGATACTGATATCTTGGCGGCATTCCGAGTCACT CCTCAACCCGGAGIGCCCCCCGAGGAAGCAGGAGCGGCAGTAGCTGCCGAATCTICCACT GGTACATGGACTACTGITTGGACCGATGGACTTACCAGCCTCGATCGTTACAAGGGGCGA TGCTATGGCATCGAACCTATTCCTGGAGAAGAARGTCAATTTATTGCCTATGTAGCTTAT CCCTTAGACCTTITTGAAGAAGTTCTGTTACTAACCTGTTCACCTCCATTGTGGGTAAT GTITTGGATTCAAAGCCCTACGGGCTATACGTCTGGAAGATCTGCGAITCCTCCTTCT TATTCCAMACTTICCAMGGTCCCCCACATGGTATCCAGGTAGRAGGGATANTTHWT AHATATGGCCGCCCCITATIGGGATGTACCATCANCCAWATTGGGTCTGTCTGChHG ARTRTGGTAGAGCAGTITACGAMTGICTTCGAGGTGGA

Fig. 3. Nucleotide sequence of the Podocarpus sample from Batanes.

TABLE I: IDENTITY OF PODOCARPUS SAMPLES COLLECTED FROM BUKIDNON AND BATANES, PHILIPPINES.

\begin{tabular}{cclccc}
\hline \hline $\begin{array}{c}\text { Isolate } \\
\text { no. }\end{array}$ & $\begin{array}{c}\text { Collection } \\
\text { area }\end{array}$ & Identification & E-value & Identity & Reference \\
\hline R1 & Bukidnon & $\begin{array}{l}\text { Podocarpus } \\
\text { macrophyllus } \\
\text { Podocarpus } \\
\text { R3 }\end{array}$ & 0.00 & $99 \%$ & JQ512600.1 \\
Batanes & 0.00 & $99 \%$ & HM593635.1 \\
\hline \hline
\end{tabular}

The unknown Podocarpus spp. from Bukidnon was identified as Podocarpus macrophyllus. In the latest revision of the genus Podocarpus following Buchholz and Gray [33], Laubenfels [34] proposed an infrageneric classification of the genus that recognized two subgenera with 18 sections. Podocarpus macrophyllus, is classified in section Polystachyus (type: P. polystachyus R. Br.) in subgenus Foliolatus. According to Laubenfels [34], section Polystachyus consists of nine species ranging from Japan and S China through Malaya to W New Guinea and NE Australia. Laubenfels distinguished Podocarpus macrophyllus from Podocarpus chinensis (Roxb.) Wall. ex J. Forbes by differences in the shape and size of the leaves; Podocarpus macrophyllus has leaves "with revolute margins, narrowing gradually at the base", and those of Podocarpus chinensis are "narrowing gradually at the base, less than $7 \mathrm{~mm}$ wide" and "at least $4 \mathrm{~cm}$ long, and at least 10 times as long as wide." Fu and Mill [35] reduced Podocarpus chinensis to synonymy under Podocarpus macrophyllus and treated it as var. maki [sensu Siebold \& Zucc.]. They distinguished the varieties by the length and width of leaves: leaves of var. macrophyllus are 7-12 cm long, (5-) 7- $10 \mathrm{~mm}$ wide, those of var. maki are 1.7-7 cm long, 5-7 mm wide [36].

The Podocarpus spp. sample from Batanes was identified as Podocarpus costalis. Podocarpus costalis, locally known as Arius, is a species of conifer in the Podocarpaceae family, found and endemic in the Philippines and Taiwan. It is sometimes misidentified as Podocarpus polystachyus $\mathrm{R}$. Brown ex Endlicher (from Indonesia, Malaysia, and the Philippines) by several authors dealing with the Chinese flora. In the Philippines, it is endemic to Palawan and Luzon. $P$. costalis is distributed in Batanes and in the Babuyan Islands in Northern Luzon. It is home to coastal bluffs near sea-level to at least 300 meters [37].

\section{CONCLUSION}

Identification of Podocarpus and Podocarpacea is often difficult. DNA barcoding technique using rbcL sequences in this study provides rapid and accurate identification of Podocarpus samples from Bukidnon and Batanes, Philippines. The sample from Bukidnon was Podocarpus macrophyllus. The sample from Batanes was identified as Podocarpus costalis. This identification may be helpful as an addition to the reference library of Podocarpaceae DNA barcodes which will allow researchers unfamiliar with the family's morphology and anatomy to make accurate identifications.

\section{ACKNOWLEDGMENT}

We thank Lessie Mae dela Cruz-Mata for the assistance in making this study.

\section{REFERENCES}

[1] Farjon A. 1998. World Checklist and Bibliography of Conifers. Kew, Richmond, UK.

[2] IUCN. 2012. International union for the conservation of nature red list of threatened species, version 2012.2. Available: http://www.iucnredlist.org.

[3] CITES. 2012. Convention on international trade in endangered species, appendices I, II, and III. Available: http://www.cites.org.

[4] McGuffin M, Kartesz JT, Leung AY, Tucker AO. 2000. Herbs of Commerce. American Herbal Products Association, 2nd edition.

[5] Fu L, Li Y, Mill RR. 1994. Podocarpaceae. In: Wu Z, Raven, PH, Hong D, editors, Flora of China, St. Louis: Missouri Botanical Garden, volume 4. pp. 78-84.

[6] Facciola S. 1990. Cornucopia: a source book of edible plants. Vista: Kampong Publications.

[7] Abdillahi HS, Stafford GI, Finnie JF, Van Staden J. 2010. Ethnobotany, phytochemistry and pharmacology of Podocarpus sensu latissimo (s.1.). South African Journal of Botany 76: 1-24. http://dx.doi.org/10.1016/j.sajb.2009.09.002

[8] Abdillahi HS, Verschaeve L, Finnie JF, Van Staden J. 2012. Mutagenicity, antimutagenicity and cytotoxicity evaluation of South African Podocarpus species. Journal of Ethnopharmacology 139: 728-738. http://dx.doi.org/10.1016/j.jep.2011.11.044

[9] Bauch J, Schmidt O, Hillis WE, Yazaki Y. 1977. Deposits in heartshakes of Dacrydium species and their toxicity against fungi and bacteria. Holzforschung 31:1-7. http://dx.doi.org/10.1515/hfsg.1977.31.1.1

[10] Symonds EL, Konczak I, Fenech M. 2012. The Australian fruit illawarra plum (Podocarpus elatus Endl., Podocarpaceae) inhibits telomerase, increases histone deacetylase activity and decreases proliferation of colon cancer cells. British Journal of Nutrition 15: 1-9.

[11] Abdillahi HS, Finnie JF, Van Staden V. 2008a. Antibacterial activity of Podocarpus species. South African Journal of Botany 74: 359-360. http://dx.doi.org/10.1016/j.sajb.2008.01.024

[12] Abdillahi HS, Stafford GI, Finnie JF, Van Staden J. 2008b. Antimicrobial activity of South African Podocarpus species. Journal of Ethnopharmacology 119: 191-194. http://dx.doi.org/10.1016/j.jep.2008.06.023

[13] Hayashi Y, Matsumoto T, Tashiro T. 1979. Antitumor activity of norditerpenoid dilactones in Podocarpus plants-structure activity relationship on in vitro cytotoxicity against Yoshida sarcoma. Gann 70: 365-369. 
[14] Hembree JA, Chang CJ, McLaughlin JL, Cassady JM, Watts DJ, et al. 1979. Cytotoxic norditerpene dilactones of Podocarpus milanjianus and Podocarpus seellowii. Phytochemistry 18: 1691-1694. http://dx.doi.org/10.1016/0031-9422(79)80185-5

[15] Hembree JA, Chang C, Mclaughlin JL, Cassady J. 1980. Milanjilactone A and milanjilactone B, 2 novel cytotoxic norditerpene dilactones from Podocarpus milanjianus. Rendle. Experientia 36: 28-29. http://dx.doi.org/10.1007/BF02003950

[16] Park HS, Takahashi Y, Fukaya H, Aoyagi Y, Takeya K. 2003. $\mathrm{S}$-R-podolactone $\mathrm{D}$, a new sulfoxide-containing norditerpene dilactone from Podocarpus macrophyllus var. maki. Journal of Natural Products 66: 282-284 http://dx.doi.org/10.1021/np020334x

[17] Park HS, Takahashi Y, Fukaya H, Aoyagi Y, Takeya K. 2004. New cytotoxic norditerpene dilactones from leaves of Podocarpus macrophyllus var. maki. Heterocycles 63: 347-357. http://dx.doi.org/10.3987/COM-03-9970

[18] de Laubenfels DJ. 1969. A revision of the Malesian and pacific rainforest conifers, i. Podocarpaceae, in part. Journal of the Arnold Arboretum 50: 315-369. http://dx.doi.org/10.5962/bhl.part.24691

[19] de Laubenfels DJ. 1988. Coniferales. Flora Malesiana 10: 337-453.

[20] Little DP, Knopf P, Schulz C. 2013. DNA barcode identification of Podocarpaceae - the second largest conifer family. PLOS ONE 8(11):1-11. http://dx.doi.org/10.1371/journal.pone.0081008

[21] Hebert PDN, Gregory TR. 2005. The promise of DNA barcoding for taxonomy. Systematic Biology 54: 852-859. http://dx.doi.org/10.1080/10635150500354886

[22] Kress、W, Erickson DL. 2007. A two-locus global DNA barcode for land plants : The coding rbcL gene complements the non-coding trnH-psbA spacer region. PLoS One 2 : e508. http://dx.doi.org/10.1371/journal.pone.0000508

[23] Erickson DL, Spouge J, Resch A, Weigt LA, Kress WJ. 2008. DNA barcoding in 1and plants : Developing standards to quantify and maximize success. Taxon 57 : 1304-1316.

[24] Newrnaster SG, Ragupathy S. 2009. Testing plant barcoding in a sister species complex of pantropical Acacia(Mimosoideae. Fabaceae). Molecular Ecology Resources 9 : 172-180. http://dx.doi.org/10.1111/j.1755-0998.2009.02642.x

[25] Valentini A, Pompanon F. Taberlet P. 2009. DNA barcoding for ecologists. Trends in Ecology \& Evolution 24 : 110-117 http://dx.doi.org/10.1016/j.tree.2008.09.011

[26] Chase MW, Cowan RS, Hollingsworth PM, Van Den Berg C, Madriňan S, Petersen G, Seberg O, Jorgsensen T, Cameron KM, Carine M, Pedersen N, Hedderson TAJ, Conrad F, Salazar GA, Richardson JE, Hollingsworth ML, Barraclough TG. Kelly L, Wilkinson M. 2007. A proposal for a standardised protocol to barcode all land plants. Taxon 56:295-299.

[27] Ford CS , Ayres L, Toomey N, Haider N, Stahl J, Kellv LJ, Wikstr6m N, Hollingsworth PM, Duff RJ, Hoot SB , Cowan RS, Chase MW , Wilkinson MJ $\cdot 2009 \cdot$ Selection of candidate coding DNA barcoding regions for use on land plants $\cdot$ Botanical Journal of the Linnean Society 159:1-11 . http://dx.doi.org/10.1111/j.1095-8339.2008.00938.x

[28] Hollingsworth ML, Clark A , Forrest LL, Richardson J , Pennington RT , Long DG , Cowan R, Chase MW, Gaudeul M • Hollingsworth PM • 2009 - Selecting barcoding loci for plants : evaluation of seven candidate loci with species level sampling in three divergent groups of land plants . Molecular Ecology Resources 9 : 439-457 . http://dx.doi.org/10.1111/j.1755-0998.2008.02439.x

[29] CBOL Plant Working Group - 2009 - A DNA barcode for land plants · Proceedings of the National Academy of Sciences USA $106: 12794-1279$ http://dx.doi.org/10.1073/pnas.0905845106

[30] Kress WJ , Erickson DL, Jones FA, Swenson NG, Perez R, Sanjur O , Bermingham E - 2009 - Plant DNA barcodes and a community phylogeny of a tropical forest dynamics plot in Panama - Proceedings of the National Academy of Sciences USA $106: 18621-18626$ • http://dx.doi.org/10.1073/pnas.0909820106
[31] Doyle J · Doyle J $\cdot 1987 \cdot$ A rapid DNA isolation procedure for small quantities of fresh leaf material - Phytochemical Bulletin 19: 11-15 ·

[32] Farjon A. 1998. World Checklist and Bibliography of Conifers. Kew, Richmond, UK

[33] Buchholz, J. T. and Gray, N. E. 1948. A taxonomic revision of Podocarpus. Journal of Arnold Arboretum 29:49-63. http://dx.doi.org/10.5962/bhl.part.26197

[34] Laubenfels, D. J. 1985. A taxonomic revision of the genus Podocarpus. Blumea 30: 251-278.

[35] Fu L, Li Y, Mill RR. 1994. Podocarpaceae. In: Wu Z, Raven, PH, Hong D, editors, Flora of China, St. Louis: Missouri Botanical Garden, volume 4. pp. $78-84$.

[36] Akiyama, S. Ohba, H. 2012. A Taxonomic Revision of Podocarpus macrophyllus (Thunb.) Sweet and its Related Taxa (Podocarpaceae). Bull. Natl. Mus. Nat. Sci., Ser. B 38(3): 121-130.

[37] http://www.cyclopaedia.info/wiki/Podocarpus-costalis 